九州大学学術情報リポジトリ

Kyushu University Institutional Repository

\title{
Survey of the Reaction Products from Urea by Urea Dehydrogenase of Perilla Leaf
}

Omura, Hirohisa

Food Chemistry Institute, Faculty of Agriculture, Kyushu University

Tsukamoto, Toru

Food Chemistry Institute, Faculty of Agriculture, Kyushu University

Tosu, Takao

Food Chemistry Institute, Faculty of Agriculture, Kyushu University

https://doi.org/10.5109/22873

出版情報: 九州大学大学院農学研究院紀要. 19 (2/3)，pp.103-112，1975-03. Kyushu University バージョン：

権利関係 : 


\title{
Survey of the Reaction Products from Urea by Urea Dehydrogenase of Perilla Leaf
}

\author{
Hirohisa Omura, Toru Tsukamoto" and Takao Tosu ${ }^{23}$ \\ Food Chemistry Institute, Faculty of Agriculture, \\ Kyushu University, Fukuoka
}

(Received November 22, 1974)

\begin{abstract}
Non-urea X-products from ${ }^{14} \mathrm{C}$-urea by the urea dehydrogenase oi perilla leaf was surveyed by the paper chromatography, the paper electrophoresis and the column chromatography with Amberlite CG 120.

At least, ${ }^{14} \mathrm{C}$-products were detected by the paper chromatography. About GO $\%$ of the total radioactivity was contained in the main products and about $12 \%, 12 \%$ or $4 \%$ in the other ones. By acid hydrolysis, a new compound was formed from the main product, but not from the others.

By the paper electrophoresis at $\mathrm{pH} 9.2$, the products moved to the anode. Through the column chromatography with sodium type of Amberlite CG 120, the products were roughly isolated. However, in both cases, the products were not separated one another. The column chromatogram of the products was compared with their paper chromatogram. The combined procedure of the column chromatography followed with the paper chromatography was suggested to be suitable for isolation of the products. By surveying the products, it was suggested that some non-urea compounds were directly formed from urea by the urea dehydrogenase, excluding a possibility of the cooperative action of the urease and the ammonium dehydrogenase.
\end{abstract}

\section{INTRODUCTION}

In our institute, it was discovered that NAD or NADP was enzymatically reduced in the presence of urea. The activity was confirmed in fowl liver, silkworm, yeast (Omura and Osajima, 1961a, b), perilla leaf (Furutani et al., 1965) and green algae (Omura et al., 1969a, b). In addition, formation of some substances which were not degradated by urease was established using " $\mathrm{C}$-urea as the substrate of the enzyme (Omura et al., 1966). By detailed elucidation of the properties, the enzyme was demonstrated to be "urea :NAD(P) oxidoreductase" or simply "urea dehydrogenase," although reaction products from urea had not been identified. It is commonly believed that urea is utilized through ammonia formed by the action of urease. Anxiety is still remained that the enzymatic reduction of NAD(P) with urea may be attributed to the action of the ammonium dehydrogenase which reduce $\mathrm{NAD}(\mathrm{P})$ with ammonia (Yamafuji $\boldsymbol{e t}$ al., 1959, 1960a, b), although some reliable evidences had been reported. In order to elucidate the reaction mechanism and the physiological function by denying the

1) Ajinomoto Co., Inc.

2) Dainihon Ink Chemicals Co. 
above possibility and to confirm that the enzyme is urea dehydrogenase, it is necessary to identify the products. The present study shows some evidences of the direct formation of non-urea compounds from urea, while the identification has not completed,

\section{MATERIALS AND METHODS}

\section{Material}

The preparation of "CC-urea employed was obtained from the Radiochemical Centre, England. Its radiochemical purity was certified to be $105 \%$ by the dilution method with urea or $100 \%$ by the paper chromatographic method.

Enzyme solution was prepared from leaf of Perilla frutescens Brittcn which had been cultivated on sterilized sand with urea as the sole nitrogen source, as described by Furutani et al. (1965). Based on the enzymatic properties, the material was prepared as follows. The reaction mixture composed of $150 \mathrm{ml}$ enzyme solution in $\mathbf{0 . 2} \mathrm{M}$ Tris- $\mathrm{HCl}$ buffer, $\mathrm{pH}$ 7.5, $50 \mathrm{mg}$ NADP, 10 pmoles ATP, $50 \mu$ moles $\mathrm{MgCl}_{2}, 50 \mu$ moles ornithine, $20 \mathrm{mg} \mathrm{FAD}, 0.75 \mathrm{mg}$ phosphate and $20 \mu \mathrm{Ci}$ ${ }^{14} \mathrm{C}$-urea in the total volume of $200 \mathrm{ml}$. After incubating it at $35^{\circ} \mathrm{C}$ for 2 hours, $20 \mathrm{mg}$ crystalline jack bean urease (Sigma Chemicals), which had been dissolved in $10 \mathrm{ml} 5 \%$ albumin, was added to the reaction mixture and incubated at $45^{\circ} \mathrm{C}$ for 30 minutes to destroy the remaining ${ }^{14} \mathrm{C}$-urea. Then, $10 \mathrm{ml} 10 \%$ trichloroacetic acid was added, heated at $70^{\circ} \mathrm{C}$ for 10 minutes and centrifuged at 10,000 r.p. m. for 10 minutes to remove protein. The supernatant was lyophilized and employed for examination as the sample $\mathrm{X}$. By assaying the radioactivity with a gas-flow Geiger-Müller counter, TEN Model SA-5A, it was found that the radioactivity of the sample $\mathrm{X}$ is $393.5 \mathrm{c}$. p. $\mathrm{m}$. per $\mathrm{mg}$, indicating that about $85 \%$ of the radioactivity of the substrate ${ }^{14} \mathrm{C}$-urea was contained in the sample $\mathrm{X}$.

\section{Paper chromatography}

An ascending paper chromatography was carried out at room temperature for 26 hours using a paper, Toyo No. 51, with n-butanol-acetic acid-water (4 : 1: 2) as the solvent. After drying the paper, W-compounds were detected by the autoradiography of the paper chromatogram exposed to Fuji X-ray film, 400 highspeed screen-type, for 20 days.

Alternatively, another solvent, phenol-water (5: 1) mixture containing 15 mg\% 8-hydroxyquinoline was employed. In this case, the ascending chromatography was conducted in an atmosphere of ammonia-gas in a vessel at room temperature for 26 hours.

\section{Paper electrophoresis}

A $0.02 \mathrm{ml}$-aliquot of the aqueous solution of the sample $(2.5 \mathrm{mg} / 0.05 \mathrm{ml})$ was submitted to the paper electrophoresis in $0.04 \mathrm{M}$ borate buffer, $\mathrm{pH} 9.2$, at $300 \mathrm{~V}$ with $20 \mathrm{~mA}$ for 3.5 hours.

\section{Column chromatography}

Ion exchange column chromatography was carried out using a sodium type of Amberlite CG 120, as for hydroxyurea (Omura et al., 1970). A 0.2 ml-aliquot of the sample solution was put on a top of the column, $150 \mathrm{~cm} \times 0.9 \mathrm{~cm}$, equili- 
brated with citrate buffer, $\mathrm{pH}$ 3.25. After washing, elution was conducted at $50^{\circ} \mathrm{C}$ with the same citrate buffer with a rate of $0.38 \mathrm{ml} / \mathrm{minute}$ controled by a pump (at $2.7-2.8 \mathrm{~kg} / \mathrm{cm}^{2}$ ) and every $2 \mathrm{ml}$ were collected in a planchet and dried under an infrared lamp. Radioactivity was estimated with a Low Back gas-flow counter. After elution with citrate buffer, the column was eluted with $0.2 \mathrm{~N}$ sodium hydroxide, when it is necessary.

\section{RESULTS}

\section{Paper chromatography}

Paper chromatogram of the sample $\mathrm{X}$ with $\mathrm{n}$-butanol-acetic acid-water is shown in Fig. 1. It is evident that at least 4 radioactive compounds (Spots A, $\mathrm{B}, \mathrm{C}$ and $\mathrm{D}$ ) were detected at $\mathrm{Rf} 0.33,0.56,0.85$ and 0.93 respectively, differing from that corresponding to urea. The result indicates that they were derived from urea and that the remaining ${ }^{14} \mathrm{C}$-urea in the reaction mixture was completely destroyed by the treatment with urease in preparing the material, the sample $\mathrm{X}$. In addition, positive ninhydrin reaction was also observed on the spots $\mathrm{A}$ and $\mathrm{D}$.

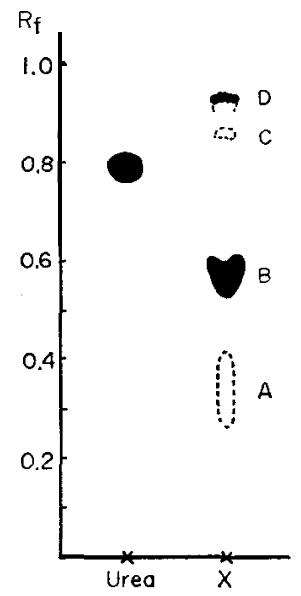

Fig. 1. Paper chromatogram of the sample X.

Then, the relative radioactivity of the spots was estimated. A $2.5 \mathrm{mg}$ aliquot of the sample $\mathrm{X}$ was dissolved in $0.05 \mathrm{ml}$ water and $0.02 \mathrm{ml}$ of the solution was quantitatively subjected to the paper chromatography as above. After chromatogram was dried, the paper strip was cut every $1 \mathrm{~cm}$ long from the original line. The radioactivity of these small pieces of the paper chromatogram was assayed by a Low Back gas-flow counter as shown in Fig. 2. The result indicates that 59-60 \% of the total radioactivity were included in the main peak $\mathrm{B}, 11 \sim 12 \%$ in $\mathrm{A}$ or $\mathrm{D}$ and about $4 \%$ in $\mathrm{C}$.

\section{Paper electrophoresis}

As in the case of Fig. 2, the dried paper strip of the electrophorogram of 


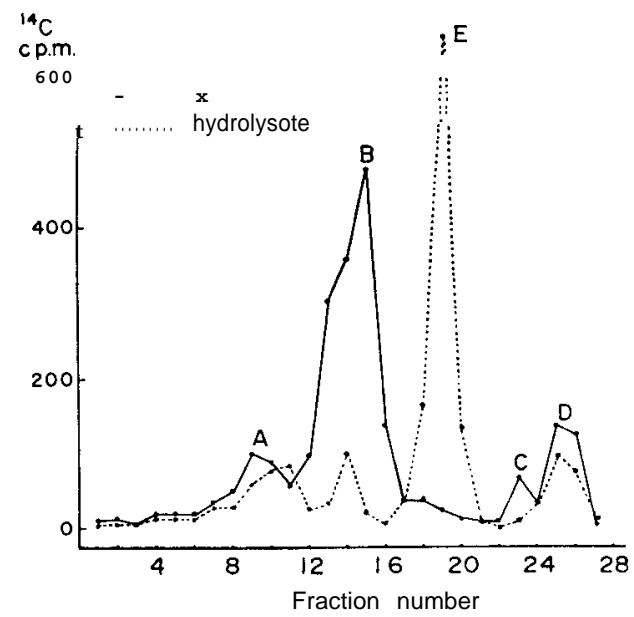

Fig. 2. Distribution of radioactivity of the sample $\mathrm{X}$ or its hydrolysed products.

the sample $X$ was cut into small pieces of $1 \mathrm{~cm}$ long and their radioactivity wa estimated. Fig. 3 indicates that the T-products moved to the anode, althougl they were not separated one another.

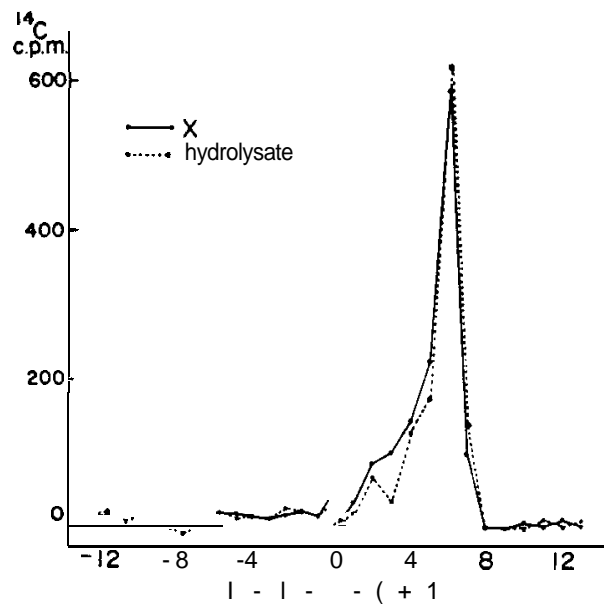

Fig. 3. Paper electrophoresis of the sample $X$ or its hydrolysed products.

\section{Hydrolysis}

It was presumed that the dehydrogenated product of urea might be labile and instantaneously combined with certain substances. Indeed, formation of non-urea compounds was enhanced by addition of ornithine (Omura et al., 1966). Since the sample $\mathrm{X}$ was prepared in the presence of ornithine, it was supposed that some of the products detected might be formed secondly from urea probably after combination with ornithine or some other substances. If the combina- 
tion is simple, urea may be liberated again by hydrolysis. In order to confirm this assumption, hydrolysis of the sample $\mathrm{X}$ was tried and examined by paper chromatography and paper electrophoresis. In a sealed small glass tube, $20 \mathrm{mg}$ of the sample $\mathrm{X}$ were heated at $100^{\circ} \mathrm{C}$ for 5 to 10 hours in $6 \mathrm{~N} \mathrm{HCl}$. Since some non-radioactive black precipitate was formed after about 1.5 hours' heating, the hydrolysate was centrifuged and the supernatant was evaporated to dryness at reduced pressure. The dried hydrolysate was dissolved in $3 \mathrm{ml}$ water. A 1 ml-aliquot of the solution was again dried, dissolved in $0.05 \mathrm{ml}$ water and 0.02 ml-portion was served for the paper chromatography. The sample $\mathrm{X}$ was also similarly treated without hydrolysis. The paper chromatograms with n-butanolacetic acid-water are shown in Fig. 4. On the other hand, the relative radioactivities of the chromatogram and the electrophorogram of 10 hours' hydrolysate of the sample $\mathrm{X}$ are comparatively indicated in Figs. 2 and 3.

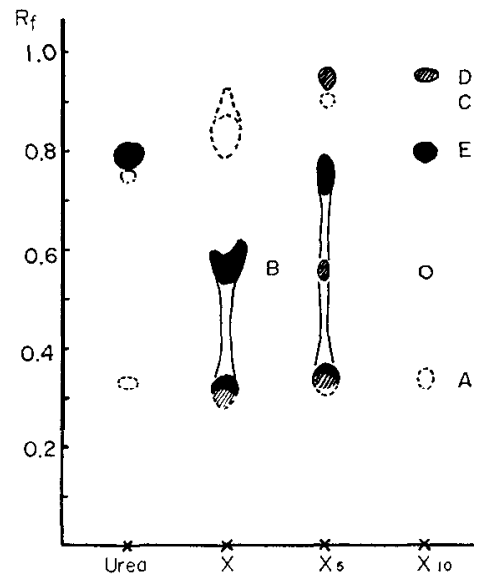

Fig. 4. Paper chromatogram of the hydrolysate of the sample $\mathbf{X}$ with butanol-acetic acid-water.

It is shown that the main spot $\mathrm{B}$ was converted to a new one $\mathrm{E}$ of $\mathrm{Rf} 0.70$ by heating in acid, although the product A was also changed a little and the product $\mathrm{C}$ was diminished, while the product $\mathrm{D}$ being unchanged. Formation of the spot $\mathrm{E}$ and disappearance of the spot $\mathrm{B}$ were increased as the time of heating has been longer, whereas appreciable variation of the others were not observed. Thus, about $55 \%$ of the total radioactivity was contained in the new spot $\mathrm{E}$ similar to the spot $\mathrm{B}$ of the original sample $\mathrm{X}$. However, distinctive separation could not be attained by the paper electrophoresis even after hydrolysis.

Furthermore, $\mathrm{Rf}$ value of the spot $\mathrm{E}$ with n-butanol-acetic acid-water coincided approximately with that of urea itself, suggesting that urea might be liberated from the main product $B$ by hydrolysis. In order to confirm it, the paper chromatography was conducted with another solvent, phenol-water. Fig. 5 clearly indicates that the Y-compounds of the sample $\mathrm{X}$ were ascended a little, although they were not separated one another. On the other hand, the hydroly- 


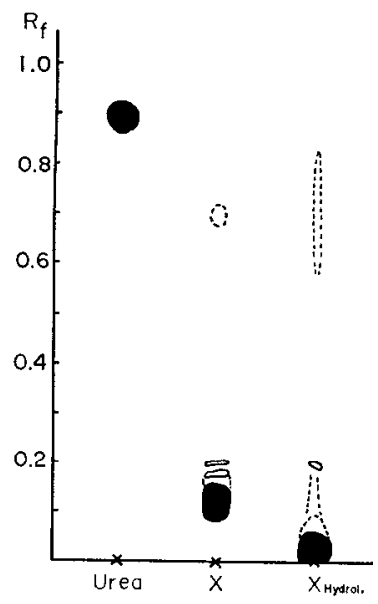

Fig. 5. Paper chromatogram of the hydrolysate of the sample $X$ with phenol-water.

sates were remained at the original place, whereas urea had higher $\mathrm{Rf}$ value. Thus, the result undoubtedly shows that the new product $\mathrm{E}$ is not urea and that urea is not formed from the sample $\mathrm{X}$ by acid hydrolysis.

This fact was decisively supported by the assay of the radioactivity after hydrolysis followed by urease treatment. A 20 mg-aliquot of the sample $\mathrm{X}$ was hydrolysed in $6 \mathrm{~N} \mathrm{HCl}$ for 10 hours and evaporated to dryness at reduced pressure. The residue was dissolved in $3 \mathrm{ml} 0.05 \mathrm{M}$ Tris- $\mathrm{HCl}$ buffer, $\mathrm{pH}$ 7.5. In a planchet, $0.5 \mathrm{ml}$ of the solution was mixed with $1 \mathrm{ml}$ urease solution in $0.05 \mathrm{M}$ phosphate buffer, pH 7.4, containing $200 \mu \mathrm{g}$ crystalline jack bean urease and incubated at $40 \sim 50^{\circ} \mathrm{C}$ for 1 hour. The reaction mixture was dried under an infrared lamp and the radioactivity was estimated. As control, $0.5 \mathrm{ml}$ of the same hydrolysed sample solution was mixed with $1 \mathrm{ml}$ phosphate buffer containing no urease and treated in parallel. Similar estimations were carried out on the sample X before hydrolysis too. The result is shown in Table 1.

Table 1. Treatment of the sample $X$ and its hydrolysate with urease.

\begin{tabular}{ccc}
\hline Sample & $\begin{array}{c}\text { Urease } \\
\text { treatment }\end{array}$ & $\begin{array}{c}\text { Radioactivity, } \\
\text { c. p. m. }\end{array}$ \\
\hline \multirow{2}{*}{ Sample X } & - & $1,138.3$ \\
Hydrolysate & + & 948.0 \\
\hline
\end{tabular}

If the new product $\mathrm{E}$ by hydrolysis is urea, the relative radioactivity should be exceedingly decreased after successive treatment with urease, since about 55 $\%$ of the total radioactivity was contained in the $\mathrm{E}$, as shown in Fig. 2. However, the radioactivity was not diminished by the action of urease, although a little decrease of the radioactivity was observed after hydrolysis. Thus, Table 
1 indicates clearly that urea is not liberated by acid hydrolysis.

\section{Column chromatography}

The column chromatogram of the sample $\mathrm{X}$ is shown in Fig. 6. Five peaks were obtained at fractions No. 21, 26, 30, 33 and 44 by citrate elution and the additional one at No. 63 with $0.2 \mathrm{~N}$ sodium hydroxide. Among them, the main peak at fraction No. 26 contained about $56 \%$ of the total radioactivity.

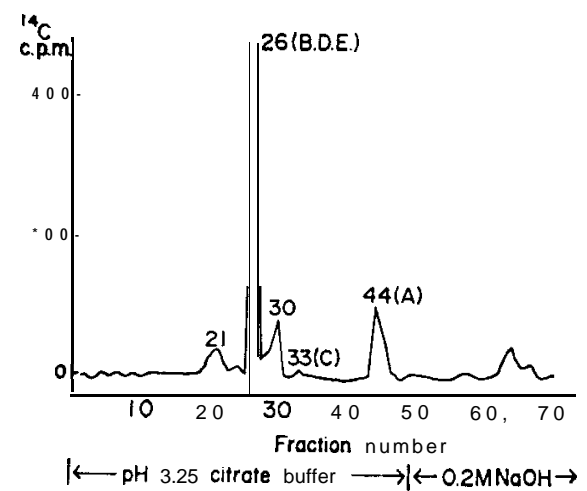

Fig. 6. Column chromatogram of the sample $X$.

Then, the products on the paper chromatogram were also examined by the column chromatography to identify them. The sample X was horizontally put on the original line of the paper in bulk and developed with n-butanol-acetic acidwater. The band corresponding to each spot was cut into small pieces, extracted with $5 \mathrm{ml} 0.1 \mathrm{~N} \mathrm{HCl}$ at $37^{\circ} \mathrm{C}$ for 24 hours and $2 \mathrm{ml}$ of the extracts were served for the column chromatography. The elution patterns of the spots B, C, D and E separated by the paper chromatography are shown in Figs. 7, 8, 9 and 10 respectively. The results indicate that the peak at fraction No. 26 contains the products $\mathrm{B}, \mathrm{D}$ and $\mathrm{E}$. On the other hand, the product $\mathrm{C}$ attributed to the peak at fraction No. 33. Extracts of the spots C and D contain some impurities, while those of the spots B and E are not contaminated. Since very small amount of the product $\mathrm{C}$ or $\mathrm{D}$ is contained in the sample $\mathrm{X}$, contaminants in $\mathrm{C}$ or $\mathrm{D}$ are not

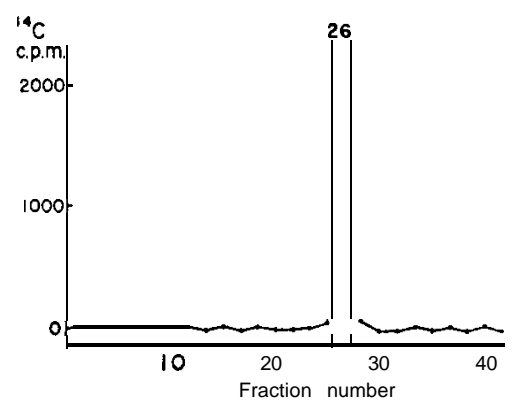

Fig. 7. Column chromatogram of the spot B. 


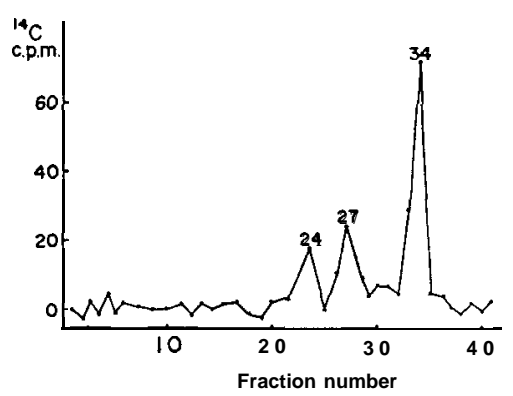

Fig. 8. Column chromatogram of the spot C.

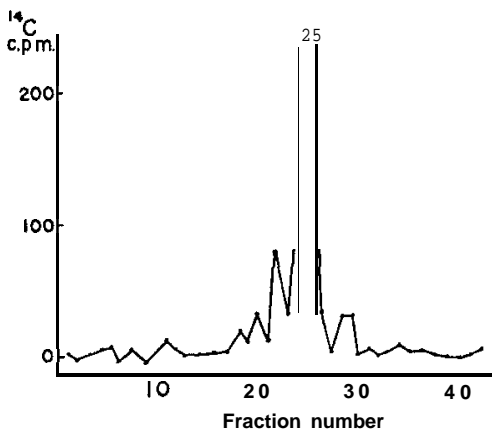

Fig. 9. Column chromatogram of the spot D.

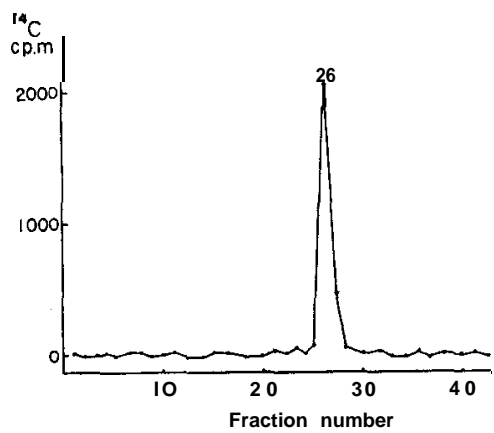

Fig. 10. Column chromatogram of the spot E.

detected by the column chromatography of the sample X, as shown in Fig. 6 .

Although the radiochemical purity of the ${ }^{14} \mathrm{C}$-urea preparation employed as the substrate had been certified to be $100 \%$, its column chromatography was also similarly conducted. However, as shown in Fig. 11, in addition to the main peak of urea, a few minor ones were observed too, even though in very low proportion. By comparing its chromatographical pattern with that of the sample $\mathrm{X}$, the minor peaks might be correspond to those at fractions No. 21, 30 and 44 


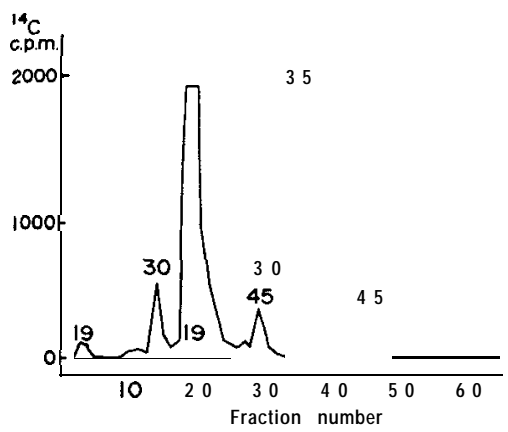

Fig. 11. Column chromatogram of the substrate W-urea employed.

of Fig. 6. Since the radioactivity of the minor peaks seemed to be kept unchanged before and after the reaction of urea with the urea dehydrogenase, they might be attributed to the impurities in the " $\mathrm{C}$-urea preparation.

\section{DISCUSSION}

Activity of the urea dehydrogenase is assayed by estimating the increase of the optical density at $340 \mathrm{~nm}$ due to the reduction of $\mathrm{NAD}(\mathrm{P})$ as the electron acceptor from urea. Similar reaction of the electron transfer from ammonia to $\mathrm{NAD}(\mathrm{P})$ is provoked by the action of the ammonium dehydrogenase too. Concerning the utilization of urea by ruminant as well as plant and microorganisms, it is prevailingly believed that urea is first decomposed to ammonia and carbon dioxide by the action of urease and ammonia formed is then employed for biosynthesis of amino acids and others. When both the urease and the ammonium dehydrogenase are contained in the enzyme solution, NAD(P) may be reduced with the cooperation of them on urea. Because their existence in the enzyme solution is established even in very low activity, the anxiety that the action of the urea dehydrogenase might be explained by the combined action of both the enzymes has been kept in mind during the course of the study on the urea dehydrogenase, although several properties of the reaction retarded it.

In the present study, non-urea ${ }^{11} \mathrm{C}$-compounds were detected in the reaction products which had been formed from "C-urea by the action of the enzyme solution of perilla leaf. If urea is utilized through ammonia, as commonly believed, ${ }^{11} \mathrm{C}$-compounds detected should be derived via " $\mathrm{C}$-carbon dioxide. However, in the assay of the urease activity, free ${ }^{14} \mathrm{C}$-carbon dioxide is easily estimated in a Conway's unit (Furutani et al., 1965), when ${ }^{14} \mathrm{C}$-urea is employed as the substrate, suggested that ${ }^{11} \mathrm{C}$-compounds are hardly formed from $\mathrm{X}$-carbon dioxide in the reaction mixture. Therefore, ${ }^{14} \mathrm{C}$-compounds detected in the present study should be directly derived from ${ }^{14} \mathrm{C}$-urea without fixing ${ }^{14} \mathrm{C}$-carbon dioxide. Thus, the result provides the additional support to the demonstration that the activity is attributed to the peculiar enzyme, urea dehydrogenase, but not to the combined action of the urease and the ammonium dehydrogenase.

Under the experimental condition employed, formation of at least $4{ }^{14} \mathrm{C}$-com- 
pounds from ${ }^{14} \mathrm{C}$-urea was established by the paper chromatography. Since ornithine was included in the reaction mixture, W-compounds might be the second products formed from dehydrogenated ${ }^{14} \mathrm{C}$-urea. Therefore, further study must be demanded in very short period of the reaction time to elucidate the direct product of urea. In addition, it is interesting that some ninhydrin-positive product was detected.

It goes without saying that the unequivocal identification of the products is necessary. The products are not completely separated among them by the ion exchange column chromatography or the electrophoresis, although a rough isolation can be performed. On the other hand, the paper chromatography is suitable for separation, while it is troublesome. Therefore, the combined procedures of the column chromatography followed by the paper chromatography may be useful for further examination.

\section{REFERENCES}

Furutani, S., H. Omura, Y. Osajima and K. Yamafuji 1965 Enzymatic study on assimilation of urea and ammonia in tissues of higher plants. Enzymologia, 28 (5) : 278-303

Omnra, H. and Y. Osajima 1961a Enzymatic reduction of DPN with urea. Nature, 190(4773) : $345-346$

Omnra, H. and Y. Osajima 1961b Comparison of enzymatic reduction of DPN with ammonia and urea. Agr. Biol. Chem., 25(6): 487-493

Omura. H., Y. Osajima and T. Tsukamoto 1966 Some properties of urea dehydrogenase in tissues of higher plants. Enzymologia, 31 (3) : 129-154

Omura, H., Y. Osajima, R. Uchio and Y. Nakamura 1969a Urea dehydrogenase of green algae (III) General properties of the enzyme. Eiyo to Shokuryo (J. Japan Soc. Food and Nutr.), 22 (3) : 139-143

Omura, H. and Y. Osajima 1969b Urea dehydrogenase of green algae (IV) Urease activity and reaction product. Eiyo to Shokuryo (J. Japan Soc. Food and Nutr.), 22(4) : 199-201

Omura, H., T. Tsukamoto, K. Shinohara and T. Tosu 1970 Urea dehydrogenase of green algae (VI) On hydroxyurea. Eiyo to Shokuryo (J. Japan Soc. Food and Nutr.), 23 (5): $344-350$

Yamafuji, K., Y. Osajima, H. Omura and T. Tanaka 1959 Ammonium dehydrogenase in animals. Enzymologia, 21 (2) : 139-144

Yamafuji, K., Y. Osajima and H. Omura 1960a Enzymatic cycle of inorganic nitrogen in animal tissues. Nature, 185 (4706) : 162

Yamafuji, K., Y. Osajima, H. Omura and S. Hatano 1960b Enzymatic cycle between ammonia and nitrate. Enzymologia, 21 (4) :245-260 